
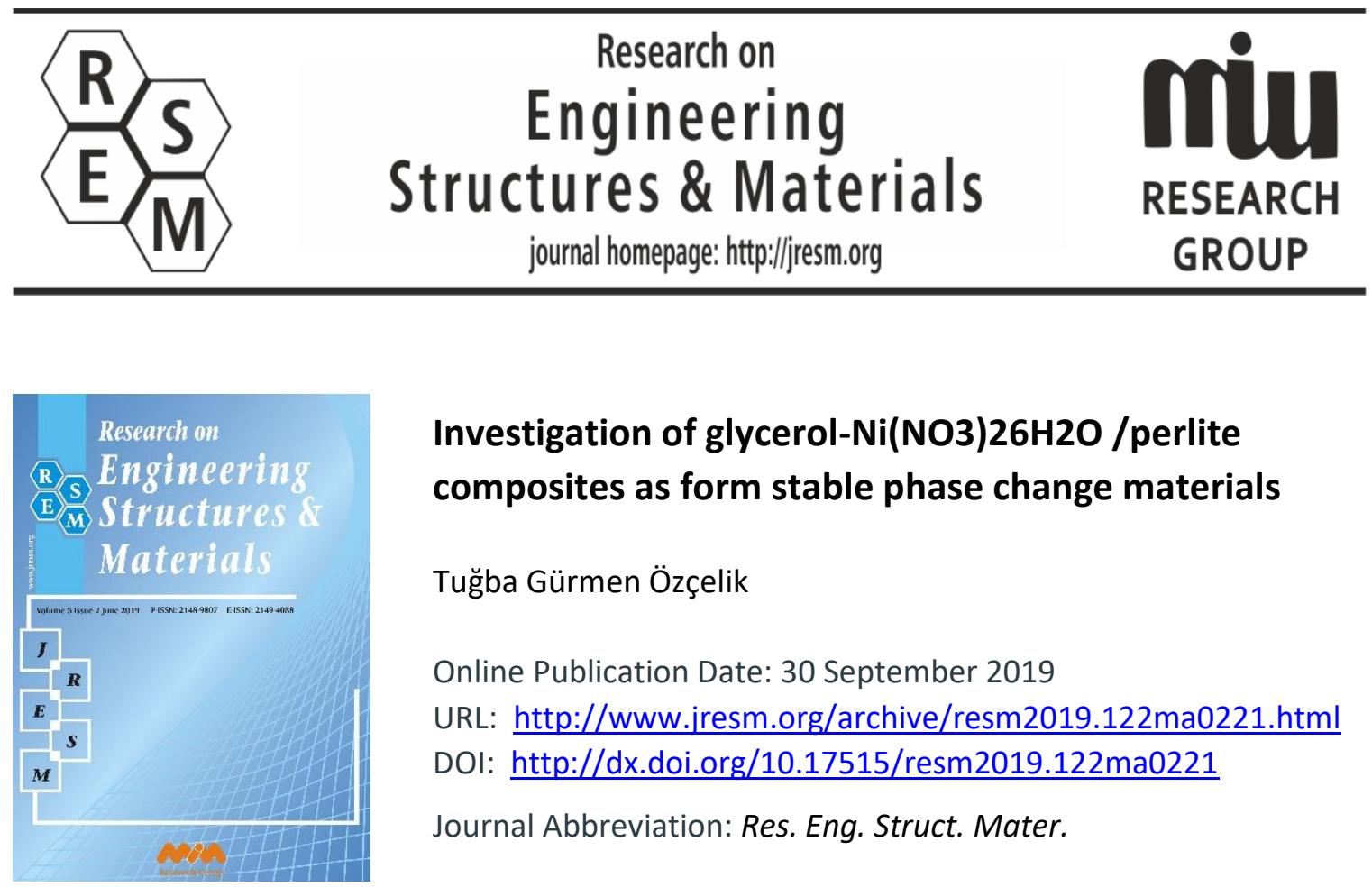

\title{
Investigation of glycerol-Ni(NO3)26H2O /perlite composites as form stable phase change materials
}

Tuğba Gürmen Özçelik

Online Publication Date: 30 September 2019

URL: http://www.jresm.org/archive/resm2019.122ma0221.html

DOI: http://dx.doi.org/10.17515/resm2019.122ma0221

Journal Abbreviation: Res. Eng. Struct. Mater.

\section{To cite this article}

Gurmen Ozcelik T. Investigation of glycerol-Ni(NO3)26H2O / perlite composites as form stable phase change materials. Res. Eng. Struct. Mater., 2020; 6(2): 141-151.

\section{Disclaimer}

All the opinions and statements expressed in the papers are on the responsibility of author(s) and are not to be regarded as those of the journal of Research on Engineering Structures and Materials (RESM) organization or related parties. The publishers make no warranty, explicit or implied, or make any representation with respect to the contents of any article will be complete or accurate or up to date. The accuracy of any instructions, equations, or other information should be independently verified. The publisher and related parties shall not be liable for any loss, actions, claims, proceedings, demand or costs or damages whatsoever or howsoever caused arising directly or indirectly in connection with use of the information given in the journal or related means.

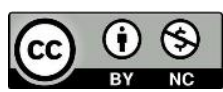
Published articles are freely available to users under the terms of Creative Commons Attribution - NonCommercial 4.0 International Public License, as currently displayed at here (the "CC BY - NC"). 


\title{
Research on Engineering Structures \& Materials
}

journal homepage: http://jresm.org

Research Article

\section{Investigation of glycerol- $\mathrm{Ni}\left(\mathrm{NO}_{3}\right)_{2} 6 \mathrm{H}_{2} \mathrm{O} /$ perlite composites as form stable phase change materials}

\author{
Tuğba Gürmen Özçelik*
}

Department of Chemical Engineering, Engineering Faculty, Ege University, Turkey.

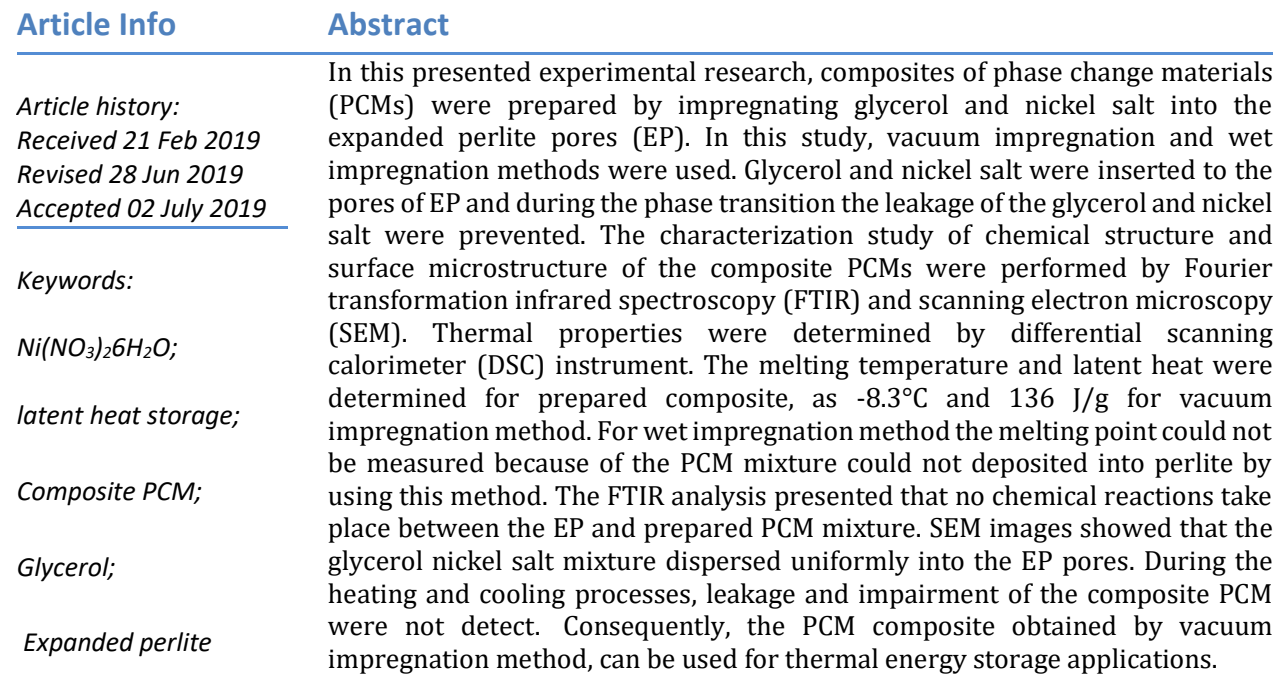

(C) 2019 MIM Research Group. All rights reserved

\section{Introduction}

Industrial development and rising population increase the energy consumption in the world. It is a known fact that the primary used energy resources of the world are going to exhausted rapidly and also the usage of traditional energy sources are main cause of the environmental pollution. Energy storage seems as a good opportunity to solve the energy problem in the world as well as to improve new renewable and clean energy sources. To meet energy needs of the developed communities, the renewable energies can be used conjunction with energy storage systems. Also, efficient and compact energy storage systems seem to be important parameters to improve the use of renewable sources. [1].

Thermal energy could be stored as latent heat, sensible heat and thermo-chemical heat. Various thermal applications may include the thermal energy storage systems. For example; solar energy panels, heating and cooling systems and heat exchangers systems in industry contains thermal energy storage systems [2,3].

Latent heat storage materials which are known as Phase change materials (PCM) have a higher energy storage capacity with a small size of the systems. They absorb and release the heat at approximately constant temperature range during the phase transitions [4].

\footnotetext{
${ }^{*}$ Corresponding author: t.gurmen.ozcelik@ege.edu.tr

a orcid.org/0000-0002-7861-0189

DOI: http://dx.doi.org/10.17515/resm2019.122ma0221

Res. Eng. Struct. Mat. Vol. 6 Iss. 2 (2020) 141-151
} 
To control the temperature in many engineering applications, phase change materials (PCM) are commonly used for thermal energy storage. According to their phase transition states, phase change materials are categorized in four groups These categories are solidsolid, solid-gas, solid-liquid, liquid-gas PCMs [2, 5, 6]. Even though liquid-gas and solid-gas phase transition have higher latent heat capacity, the volume change during the phase transition is immoderate. This volume change makes the systems more complex and ineffective [2]. Because of this reason, solid-liquid and solid-solid phase changes are preferred and investigated from the many researchers. The solid liquid phase change materials are categorised in three main groups according to their chemical structure: inorganic, organic and eutectic. Although inorganic PCMs have more latent heat capacity than the organic PCMs, phase separation and subcooling may happen during the phase transition. The organic PCMs provide many advantages; for example, generally, they are not toxic, noncorrosive, and crystallize with no super cooling and segregation. Organic PCMs are examined in two group: paraffin and non-paraffin [3- 6]. An eutectic mixture comprising two or more components forms as composition with a minimum melting point. During the crystallization every component in the mixture melts and freeze and the composition of the formed component crystals is compatible with each other [7]. The eutectic mixture may melt and freeze without phase separation because of their crystal structures. The components in the mixture melt at the same time without segregation [3].

Hydrate salts as inorganic PCMs, have some advantages of constant phase change temperature, higher heat storage capacity (nearly $300 \mathrm{~J} / \mathrm{g}$ ) comparatively high thermal conductivity $\left(0.5 \mathrm{~W} / \mathrm{m}^{\circ} \mathrm{C}\right)$ and moderate costs. They are also nonflammable and nontoxic. Thus, it may be more suitable and safer than organic PCMs in energy storage processes. The most researchers have studied with hydrate salts and eutectic mixture of the hydrate salts [8].

To prevent liquid leakage during the solid-liquid phase change, the porous materials are generally used as supports. Graphite, expanded graphite, aluminum powder, expanded perlite, activated carbon, and carbon nanotubes are chosen to keep off the liquid leakage.

Expanded perlite (EP) is an amorphous glassy volcanic rock and having porous structure. Because it has very low thermal conductivity $\left(0.03-0.05 \mathrm{~W} / \mathrm{m}^{\circ} \mathrm{C}\right)$, low sound transition property and nonflammability it is generally used as insulation material in buildings $(9$, 10). Also, some researchers reported that, EP have a good supporting matrix for preparing composite PCMs. At the same time, PCM composites which are prepared by using expanded perlite exhibit a reduced thermal conductivity $[10,11,12]$. Li et al. have studied shapestabilized PCMs by impregnating of paraffin into the expanded perlite pores. They used vacuum impregnation method and produced heat storage boards by adding gypsum into the prepared composite for use in buildings [13]. Z. Lu et al. prepared and examined formstable PCMs and using the direct impregnation method to absorb the paraffin into the pores of the EP, their results showed that the leakage was prevented [14]. Karaipekli and Sarl studied Capric-myristic acid/EP composite as phase change materials they used vacuum impregnation method and the prepared composite PCM had good thermal properties and stable for thermal applications [15].

Although PCMs prepared with organic-organic eutectics and inorganic salts and their eutectic mixtures have been widely studied in the literature, there are not many studies about the organic-inorganic eutectics. The aqueous salt solutions are used as PCM for low temperature applications, but these may cause the erosion. In this research, an organicinorganic eutectic mixture of Glycerol- $\mathrm{Ni}\left(\mathrm{NO}_{3}\right)_{2} 6 \mathrm{H}_{2} \mathrm{O}$ were studied for low temperature applications and form stable Glycerol- $\mathrm{Ni}\left(\mathrm{NO}_{3}\right)_{2} 6 \mathrm{H}_{2} \mathrm{O}$ /Expanded perlite composites were prepared by using wet impregnation and vacuum impregnation methods. Both methods are inexpensive and eco-friendly method for the composite PCM preparation. The 
prepared Glycerol-Ni $\left(\mathrm{NO}_{3}\right)_{2} 6 \mathrm{H}_{2} \mathrm{O}$ eutectic mixture was enclosed into the porous of the EP and in this way the leakage was prevented during the phase transitions. Differential scanning calorimeter (DSC) and thermo gravimetric analysis instrument (TGA) were used to analyze thermal properties and stability of prepared composite. The surface area and pore volume of the EP and composite were determined nitrogen adsorption analyses for Brunauer-Emmett-Teller (BET). The structures and morphologies of the perlite and Glycerol-Ni $\left(\mathrm{NO}_{3}\right)_{2} 6 \mathrm{H}_{2} \mathrm{O}$ composites were determined by Fourier transformation infrared spectroscope (FTIR) and scanning electronic microscope (SEM). Heating and cooling cycle tests were performed to define heat accumulation and heat release properties of PCMs.

\section{Experimental Study}

\subsection{Materials}

Glycerol and the metal salt of Nickel $\left(\mathrm{Ni}\left(\mathrm{NO}_{3}\right)_{2} 6 \mathrm{H}_{2} \mathrm{O}\right)$ were purchased from Merck. Expanded Perlite (EP) was supplied by the Batıçim-AS Company, Turkey. It was heated in an oven at $110^{\circ} \mathrm{C}$ before using.

\subsection{Methods}

Before beginning the composite PCM preparation, the eutectic point of mixture of glycerol and $\mathrm{Ni}\left(\mathrm{NO}_{3}\right)_{2} 6 \mathrm{H}_{2} \mathrm{O}$ was calculated to decide the compositions which gives lower melting point. The Schroder equation (1) was used for calculation of the eutectic point [7].

$$
\ln x_{B}=-\frac{\Delta H_{B}}{R}\left(\frac{1}{T}-\frac{1}{T_{m B}}\right)
$$

where $\Delta H$ is latent heat, $T_{m}$ is melting temperature as $K$, subscript $B$ indicates the one of the components into mixture.

Then the PCM mixture was prepared in these compositions. The prepared PCM mixture included 97 wt. \% glycerol and $3 w t . \% ~ N i\left(\mathrm{NO}_{3}\right)_{2} 6 \mathrm{H}_{2} \mathrm{O}$. Evaluated melting point of mixture at this concentration is $-10^{\circ} \mathrm{C}$.

Initially, PCM mixture was prepared. Nickel salt was weighed and melted at $57^{\circ} \mathrm{C}$ in a backer and weighed glycerol was added in the salt and mixed during 1 hour, at $1000 \mathrm{rpm}$ to obtain homogeny solution. To enclose the mixture into EP pore, two different methods were used (Wet impregnation and vacuum impregnation). Firstly, wet impregnation method was applied. EP was added to prepared mixture solution and the resulting slurry was put in an ultrasonic bath at $50^{\circ} \mathrm{C}$ for 30 minutes to penetrate the solution into the EP pores. Finally, the obtained composite was placed into an oven at $60^{\circ} \mathrm{C}$ for 10 hours. Secondly, vacuum impregnation method was used. Weighed EP was placed in the vacuum set and the prepared mixture was added it slowly under vacuum at $50^{\circ} \mathrm{C}$. Then, the obtained mixture was placed into an oven at $60^{\circ} \mathrm{C}$ for 10 hours.

The experimental set up of the vacuum impregnation is shown in Figure 1. 


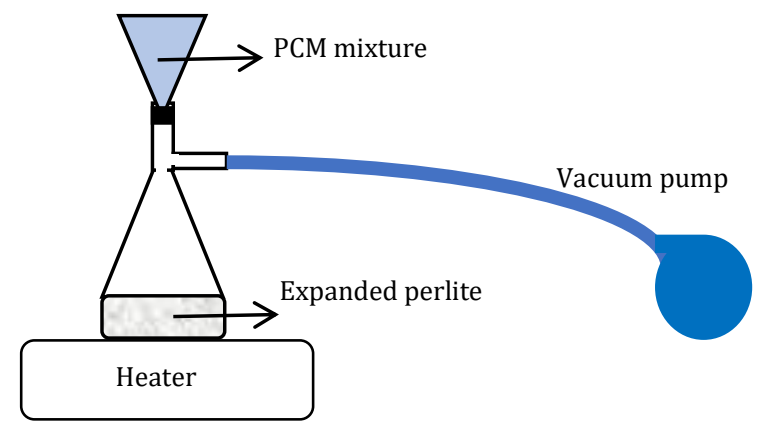

Figure 1 Experimental set-up for vacuum impregnation

To perform heating and cooling cycles, specific measure of prepared composite sample was placed into a glass tube and for recording the temperature a thermometer was put in the center of the tube. The tube was located in the hot water at $40^{\circ} \mathrm{C}$ for heating. When the temperature of the composite in the tube was reached steady state, the sample tube was carried into chilled water alcohol bath at $-15^{\circ} \mathrm{C}$ for cooling. The temperature of the composite sample in the tube was measured with time while the heating and cooling process performed. 100 heating cooling cycles were performed to specify the prepared composite reliability.

\section{Results and Discussions}

\subsection{Leakage Tests}

To determine the absorption capacity of the EP for the eutectic mixture, leakage test was performed. Before the leakage test, PCM composite, containing $50 \mathrm{wt} \%$ of perlite was prepared. This prepared PCM composite was placed on the filter paper and allowed to stand in an oven at $20^{\circ} \mathrm{C}$ for $30 \mathrm{~min}$. The prepared PCM composite exhibits no leakage as shown in Figure 2.
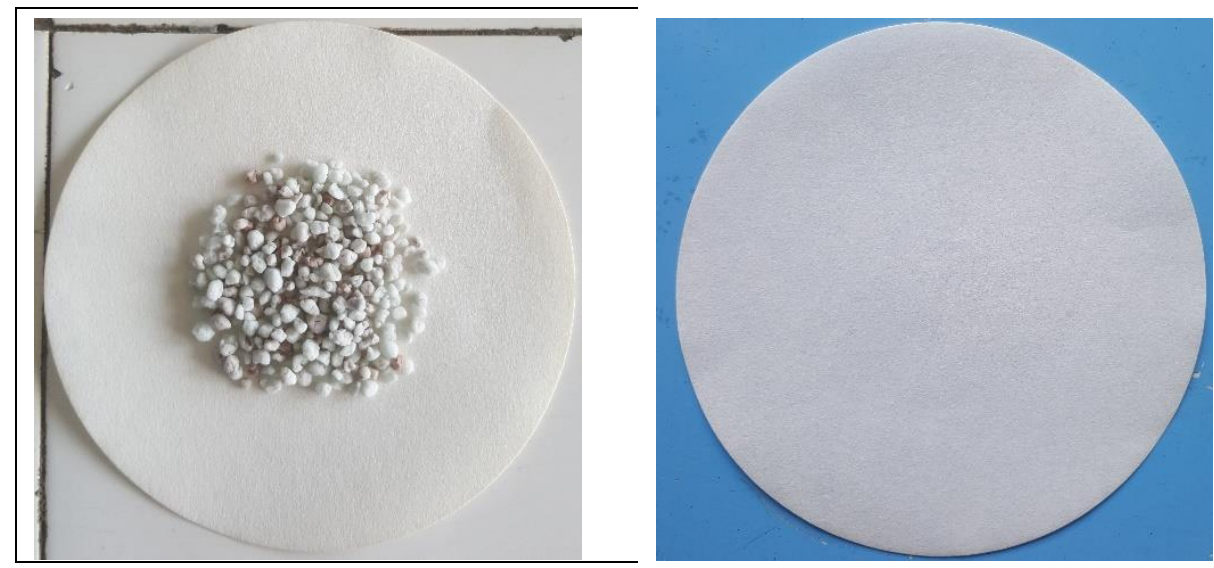

Figure 2. Images of the leakage test of the composite PCM 


\subsection{Characterization of chemical compatibility between the eutectic mixture and EP}

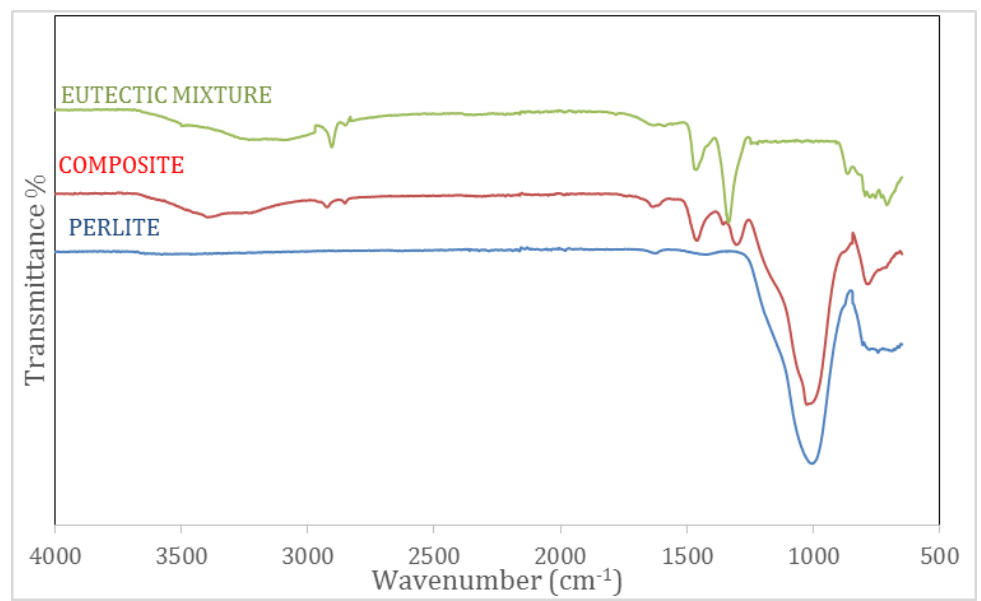

Figure 3. FTIR Spectrum of perlite, eutectic mixture and prepared composite PCM

The FTIR spectrum of expanded perlite, eutectic mixture and prepared PCM composite are shown in Figure 3. In the FTIR spectrum of the EP, the absorption band nearly at 850-900 $\mathrm{cm}^{-1}$ represents to the vibrations of the $\mathrm{Al}-\mathrm{OH}-\mathrm{Al}$ and $\mathrm{Al}-\mathrm{OH}-\mathrm{Mg}$ groups, respectively. The intense and deep peak at $1020 \mathrm{~cm}^{-1}$ is described the Si-O-Si symmetric vibrations. The weak peak at $1625 \mathrm{~cm}^{-1}$ is described to the bending modes of the $\mathrm{OH}$ groups which are appended to the surface of expanded perlite and the adsorbed water molecules on the perlite [22]. In the FTIR spectra of PCM composite, which included perlite, glycerol and nickel salt, a medium absorption bands around $1300 \mathrm{~cm}^{-1}$ and $1360 \mathrm{~cm}^{-1}$ confirm the $\mathrm{C}-0$ stretching modes of glycerol. The symmetrical stretching vibration of $\mathrm{CH}_{2}$ group which is stretching modes of glycerol is also shown at $2845 \mathrm{~cm}^{-1}$. Intense and broad band in the range between 3000 and $3600 \mathrm{~cm}^{-1}$ shows the vibration of $\mathrm{OH}$ from coordinated those strong hydrogen bonds of water. The peak at $1458 \mathrm{~cm}^{-1}$ confirms the presence of the $\mathrm{NO}_{3}$ from the nitrate salt in the composite. The band at $780 \mathrm{~cm}^{-1}$ can be assigned the Ni-O stretching vibration.

According to the FTIR spectrum of the composite, only the expended perlite, glycerol and $\mathrm{Ni}\left(\mathrm{NO}_{3}\right)_{2} 6 \mathrm{H}_{2} \mathrm{O}$ peaks are seen, there are not observed new peaks. These specify that there is no chemical reaction between the prepared PCM mixture and the expended perlite. The FTIR results show that the prepared composite is only a physical combination of the expanded perlite, glycerol and $\mathrm{Ni}\left(\mathrm{NO}_{3}\right)_{2} 6 \mathrm{H}_{2} \mathrm{O}$.

\subsection{Microstructure of expanded perlite and PCM composite}

The BET surface area and micropore volume of EP and prepared composite were determined. According to the result the used expanded perlite BET surface area and pore volume are obtained $112.3 \mathrm{~m}^{2} / \mathrm{g}$ and $0.63 \mathrm{~cm}^{3} / \mathrm{g}$ respectively. After vacuum impregnation of eutectic mixture PCM into the EP pores, BET surface area and pore volumes were decrease to $0.0345 \mathrm{~m}^{2} / \mathrm{g}$ and $0.000007 \mathrm{~cm}^{3} / \mathrm{g}$, respectively These significantly decrease shows that the PCM mixture was placed into the EP pores.

Figure $4 \mathrm{a}$ and Figure $4 \mathrm{~b}$ show the SEM images of the expanded perlite and composite PCM prepared by vacuum impregnation method, respectively. It can be seen from Figure 4-a, 
the expanded perlite has a highly porous structure having many micro-pores with different sizes. These structures make the expanded perlite as a good supporting material to keep the PCM mixture. As seen from Figure 4-b, PCM mixture were dispersed uniformly in the porous and the sheets of the EP and the composite shows the most favorable homogenous morphology.

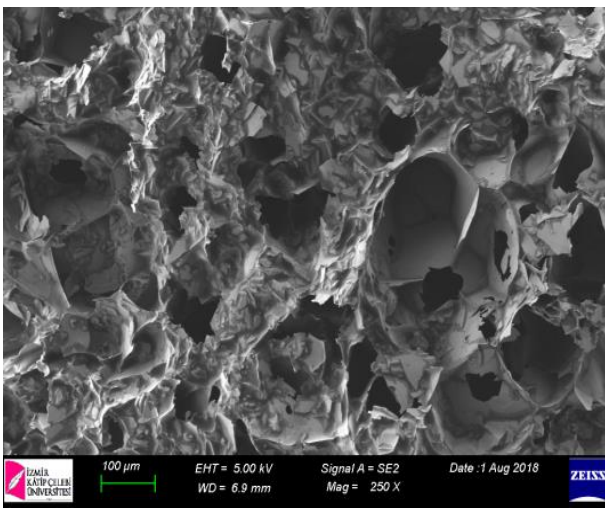

a)

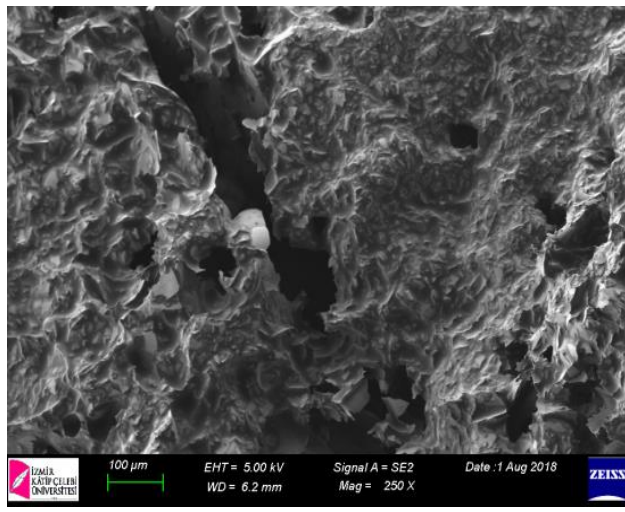

b)

Figure 4. SEM images of a) expanded perlite, b) PCM composite prepared by vacuum impregnation method.

\subsection{Thermal properties of eutectic mixture and PCM composite}

The melting and freezing temperatures and latent heat values of the prepared PCM mixture and composites are listed in Table 1. DSC curves of PCM mixture and prepared composite with vacuum impregnation method before and after thermal cycling test are given in Figure 5. According to the DSC analysis from the PCM prepared using two different methods, there were observed no peaks in the wet impregnation method. It is thought that the PCM mixture could not be enclosed into the EP pores by using this method.

Table 1. Thermal properties of PCM

\begin{tabular}{ccccc}
\hline & $\begin{array}{c}\text { Melting } \\
\text { Point } \\
\left({ }^{\circ} \mathrm{C}\right)\end{array}$ & $\begin{array}{c}\text { Melting Latent } \\
\text { Heat } \\
(\mathrm{J} / \mathrm{g})\end{array}$ & $\begin{array}{c}\text { Freezing } \\
\text { Point } \\
\left({ }^{\circ} \mathrm{C}\right)\end{array}$ & $\begin{array}{c}\text { Freezing } \\
\text { Latent Heat } \\
(\mathrm{J} / \mathrm{g})\end{array}$ \\
\hline $\begin{array}{c}\text { PCM Mixture } \\
\text { Wet }\end{array}$ & -9.7 & 165 & -9.8 & 163 \\
$\begin{array}{c}\text { Impregnation } \\
\text { Vacuum Impregnation }\end{array}$ & - & - & - & - \\
Vacuum Impregnation & -8.3 & 134 & -8.2 & 136 \\
(After100 cycle test) & -8.4 & 130 & -8.1 & 136 \\
\hline
\end{tabular}




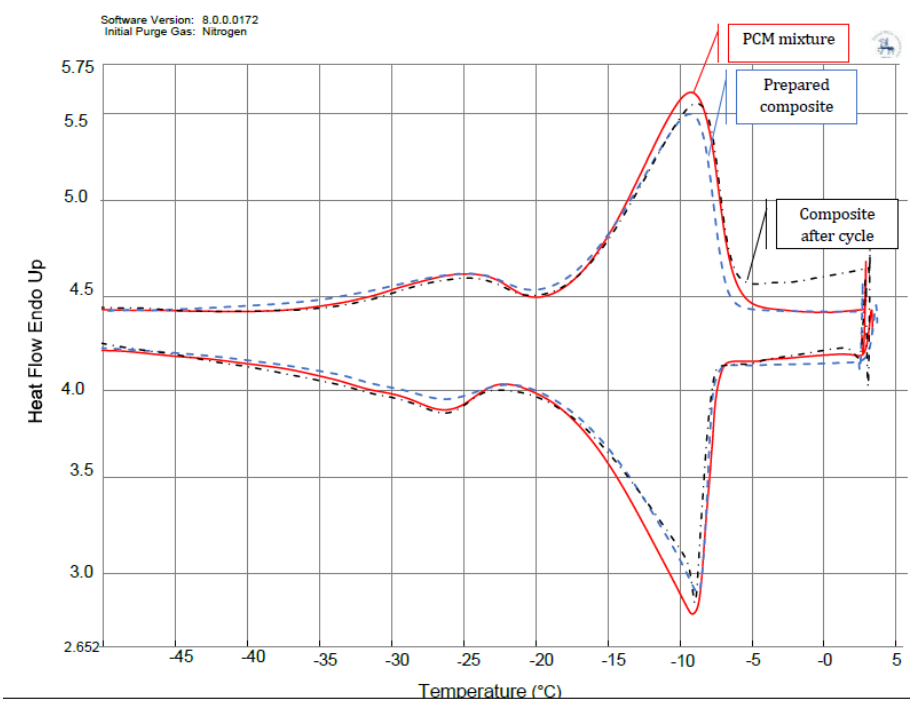

Figure 5. DSC curves for prepared composite PCM

According to DSC results, the phase transition temperatures of composite PCM which prepared by using vacuum impregnation method were about $1.4^{\circ} \mathrm{C}$ higher than that of the prepared eutectic mixture. On the other hand, the latent heats prepared composite PCM were found to be lower than the latent heats of the PCM eutectic mixture. The changes of the phase transition temperatures and the latent heat values are an indication of the force of the interactions between the expanded perlite and PCM mixture. When there is a strong relation between the PCM and pores of the support, the phase change temperature may increase and the same results have been found by some researchers for different composites [15, 16, 17 and 18]. The reduction of the latent heat value can be explained as the physical relation between the EP pores and eutectic mixture. C. Wang et al. have referred that the interaction between PCM and its support material cause the decrease of latent heat value [16]. Karaipekli and Sarı prepared eutectic mixture of capric and myristic acid and impregnated it into the EP by using vacuum impregnation method and they obtained form stable composite PCM. According to their results, melting and freezing temperatures of the eutectic mixture and prepared composite were determined as 22.61, $21.18^{\circ} \mathrm{C}$ and $21.70,20.70^{\circ} \mathrm{C}$, respectively [15]. Galazutdinova et.al. studied with inorganic composite mixture includes $40 \%$ of $\mathrm{MgCl}_{2} \cdot 6 \mathrm{H}_{2} \mathrm{O}$ and $60 \%$ of $\mathrm{Mg}\left(\mathrm{NO}_{3}\right)_{2} \cdot 6 \mathrm{H}_{2} \mathrm{O}$. The prepared inorganic mixture, melting temperature and latent heat value were obtained as $62{ }^{\circ} \mathrm{C}$ and $120 \mathrm{~J} / \mathrm{g}$. Vacuum impregnation method was used to enclose the $\mathrm{MgCl}_{2} \cdot 6 \mathrm{H}_{2} \mathrm{O}-\mathrm{MgCl}_{2} .6 \mathrm{H}_{2} \mathrm{O}$ mixture into EP. The prepared composite PCM had melting temperature of $63.5^{\circ} \mathrm{C}$ and latent heat of $106.8 \mathrm{~J} / \mathrm{g}$ [19]. Zang et all investigated $\mathrm{MgCl}_{2} .6 \mathrm{H}_{2} \mathrm{O}-\mathrm{CaCl}_{2} .6 \mathrm{H}_{2} \mathrm{O}$ Eutectic/EP composite PCM. The prepared eutectic mixture included $15 \% \mathrm{MgCl}_{2} \cdot 6 \mathrm{H}_{2} \mathrm{O}$. The melting temperature and latent heat were determined as $23.9^{\circ} \mathrm{C}, 151.9 \mathrm{~J} / \mathrm{g}$, respectively. Composite PCM including $50 \mathrm{wt} \%$ of EP was prepared by using this eutectic mixture. The $\mathrm{MgCl}_{2} .6 \mathrm{H}_{2} \mathrm{O}$ $\mathrm{CaCl}_{2} .6 \mathrm{H}_{2} \mathrm{O} / \mathrm{EP}$ composite had exhibited a melting point of $23.5^{\circ} \mathrm{C}$ and latent heat of 73.55 $\mathrm{J} / \mathrm{g}$, and there was no leakage seen after leakage tests [20]. Yllmaz et al. developed binary mixtures of tridecane and dodecane to be used as PCMs for thermal energy storage in 
cooling applications. The melting point and heat of fusion of their PCM was found as $-9.1^{\circ} \mathrm{C}$ and $145 \mathrm{~J} / \mathrm{g}$ [21].

The thermal reliability is the important point to evaluate the PCM composite performance. The thermal properties of the materials can change after many thermal cycles and latent heat and phase change temperatures may change significantly. A suitable composite PCM should have steady thermal properties with many phase changes cycles without degradation $[8,10,15]$. DSC results show that, the latent heat value and phase change temperatures of the prepared composite PCM remained nearly constant after 100 heating and cooling cycles.

\subsection{Thermal stability of PCM composite}

TGA is commonly used to determine the thermal stability of the composites, In Figure 6, the TGA curves composite PCM is shown. The weight loss of the composite starts nearly $80 \mathrm{C}$. Due to the evaporation of glycerol the decomposition amount increased rapidly after $150^{\circ} \mathrm{C}$ this temperature and $58 \%$ weight loss were measured at $350^{\circ} \mathrm{C}$. Before $150^{\circ} \mathrm{C}$, only $5 \%$ decomposition is seen.

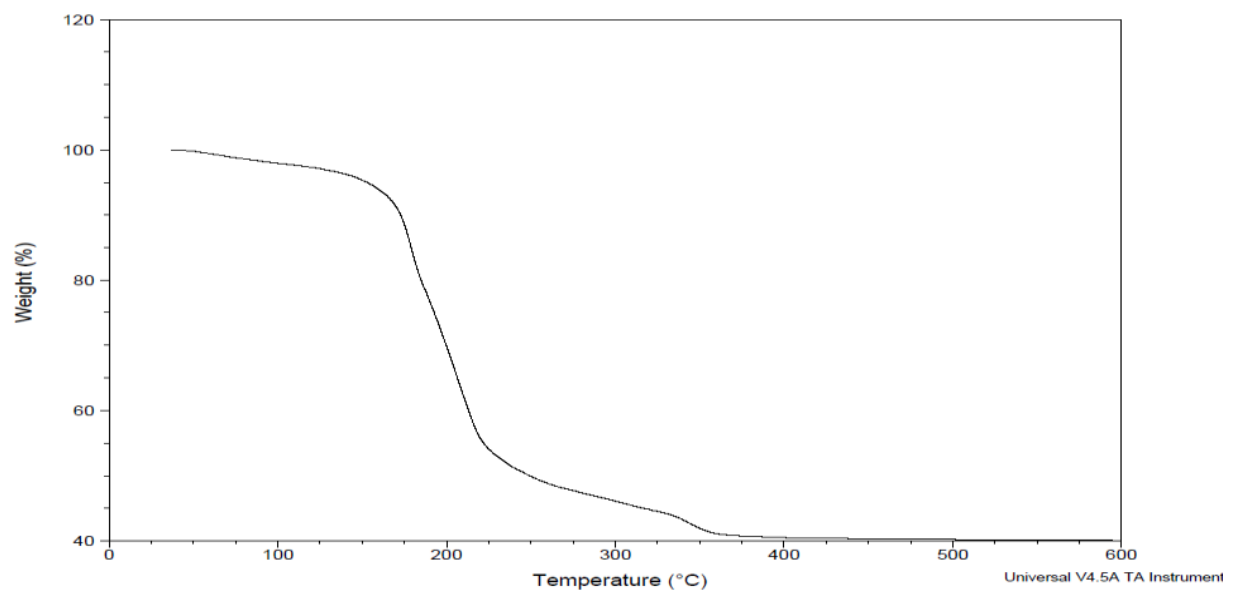

Figure 6. TGA curves of PCM composite

Heating and cooling cycles were performed to the PCM mixture and prepared PCM composite. The recorded results were drawn as temperature versus time graphic that is given in Figure 7. Each cycle of the heating and cooling were performed 20 min to obtain the steady state temperature. Figure 7 shows that, the heating and cooling rate of the prepared composite are lower than that of the PCM mixture. 


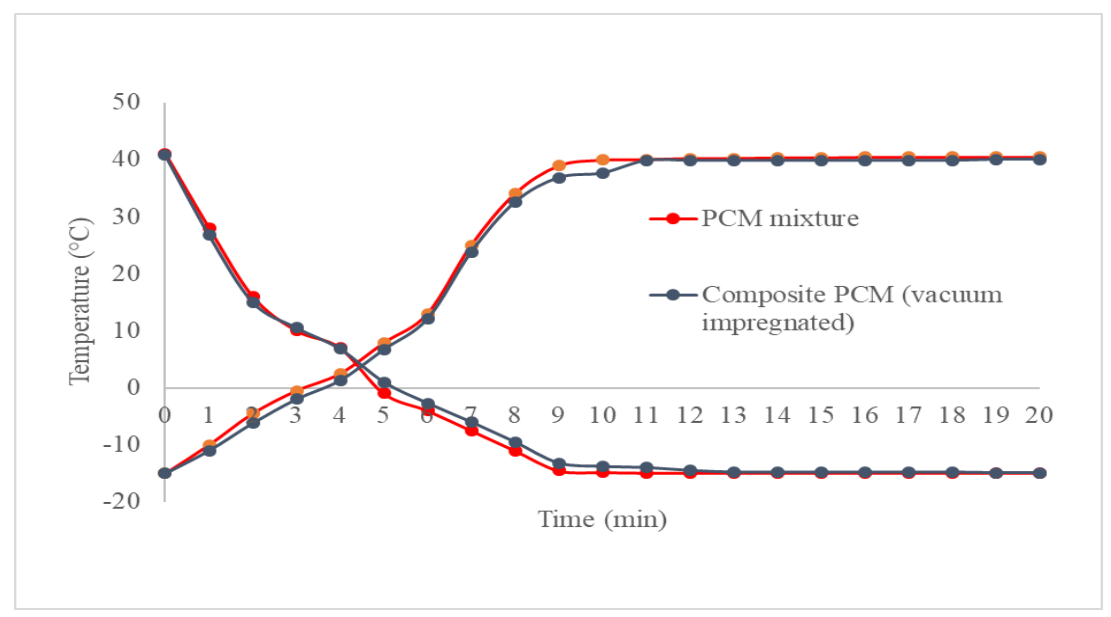

Figure 7. Heating and cooling processes for PCM mixture and PCM composites

\section{Conclusion}

In this work, Glycerol-Ni( $\left(\mathrm{NO}_{3}\right)_{2} 6 \mathrm{H}_{2} \mathrm{O} / \mathrm{EP}$ composite PCMs were prepared by using wet impregnation and vacuum impregnation methods. The used both methods are environmentally safe and economical therefore they are suitable to fabrication of PCM composite for industrial applications. But, according to the DSC analysis, there were not observed any phase change point by using wet impregnation method. It is thought that the PCM mixture could not be enclosed into the EP pores by using this method. Before preparation of the PCM mixture, eutectic point of the Glycerol- $\mathrm{Ni}\left(\mathrm{NO}_{3}\right)_{2} 6 \mathrm{H}_{2} \mathrm{O}$ mixture was determined as melting point at $-10^{\circ} \mathrm{C}$, with $97 \mathrm{wt} . \%$ glycerol and $3 \mathrm{wt} . \% \mathrm{Ni}\left(\mathrm{NO}_{3}\right)_{2} 6 \mathrm{H}_{2} \mathrm{O}$ concentrations and the mixture were prepared at calculated composition, then it was absorbed into perlite pores.

The melting point of PCM mixture and PCM composite which prepared by using vacuum impregnation were found -9.7 and $-8.3^{\circ} \mathrm{C}$ respectively. And phase change enthalpy values were determined $165 \mathrm{~J} / \mathrm{g}$ for PCM mixture and $134 \mathrm{~J} / \mathrm{g}$ for PCM composite. The changes of the melting and freezing temperatures are an indication of the force of the interactions between the EP and PCM mixture. The decrease on the latent heat values depending on the relation between the EP and PCM mixture. After heating and cooling cycles performed the composite PCM retained its melting and freezing temperatures and latent heat values. SEM images show that PCM mixture was distributed uniformly in the porous and the sheets of the EP and the composite shows the most favorable homogenous morphology. The leakage test show that the phase change process takes place in the pores of the EP. There were no leakages obtained. According to the FTIR results the eutectic PCM mixture and EP keep their original structure in the composite and the composite PCM was only the physical combination of nickel salt, glycerin and EP. After the heating cooling cycle, there was no leakage and degeneration at the composite PCM. TGA results revealed that the prepared composite has good energy storage capacities, good thermal reliability and stability.

Based on the obtained results, the presented composite PCM provide many properties of shape stabilization, moderate latent heat value and good thermal stability. In conclusion, it can be said that the prepared composite PCM has a great potential for the use in low temperature applications of thermal energy storage. 


\section{References}

[1] Trigui, A., Karkri, M., Krupa, I., Thermal conductivity and latent heat thermal energy storage properties of LDPE/wax as a shape-stabilized composite phase change material, Energy Conversion and Management, 2014, 77, pg. 586-596. https://doi.org/10.1016/j.enconman.2013.09.034

[2] Prakash J., Garg H.P., Datta G., A Solar Heater with a Built-in Latent Heat Storage, Energy Conversion and Management,1985, 25, pg. 51-56. https://doi.org/10.1016/01968904(85)90069-X

[3] Sharma A., Tyagi V.V., Chen C.R., Buddhi D., Review on Thermal Energy Storage with Phase Change Materials and Applications, Renewable and Sustainable Energy Reviews 2009, 13, pg. 318-345 https://doi.org/10.1016/i.rser.2007.10.005

[4] Yuan Y. ,Zhang N., Tao W., Cao X. , He Y. ,Fatty acids as phase change materials: A review Renewable and Sustainable Energy Reviews, 2014, 29, pg. 482-498. https://doi.org/10.1016/j.rser.2013.08.107

[5] Rathod M. K., Banerjee J, Thermal Stability of Phase Change Materials Used in Latent Heat Energy Storage Systems: A review, Renewable and Sustainable Energy Reviews 2013, 18, pg. 246-258. https://doi.org/10.1016/i.rser.2012.10.022

[6] Jamekhorshid A. , Sadrameli S.M., Farid M., A Review of Microencapsulation Methods of Phase Change Materials (PCMs) As a Thermal Energy Storage (TES) Medium, Renewable and Sustainable Energy Reviews 2014,31 ,pg. 531-542. https://doi.org/10.1016/j.rser.2013.12.033

[7] George A., Hand book of thermal design. [chapter 1],In: Guyer C, editor. Phase change thermal storage materials. McGraw Hill Book Co.; 1989.

[8] Farid Mohammed M., Khudhair Amar M., Razack Siddique Ali K. , Al-Hallaj Said, A review on phase change energy storage: materials and applications Energy Conversion and Management, 2004, 45, pg. 1597-1615. https://doi.org/10.1016/j.enconman.2003.09.015

[9] Won J.-P., Kang H.-B., Lee S.-J., Lee S.-W., KanJ.-W. g, Thermal characteristics of highstrength polymer cement composites with lightweight aggregates and polypropylene fiber, Constr. Build. Mater., 2011, 25-10, pg. 3810-3819. https://doi.org/10.1016/i.conbuildmat.2011.03.023

[10] Ye R., Fang X., Zhang Z., Gao X., Preparation, mechanical and thermal properties of cement board with expanded perlite based composite phase change material for improving buildings thermal behavior, Materials, 2015, 12, pg. 7702-7713. https://doi.org/10.3390/ma8115408

[11] Zhang D., Tian S., Xiao D., Experimental Study on The Phase Change Behavior of Phase Change Material Confined in Pores, Solar Energy, 2007, 81, pg. 653-660. https://doi.org/10.1016/j.solener.2006.08.010

[12] Kong X.F., Zhong Y.L., Rong X., Min C.H., Qi C.Y., Building energy storage panel based on paraffin/expanded perlite: preparation and thermal performance study, Materials 2016, 9, pg. 70-75. https://doi.org/10.3390/ma9020070

[13] Li M., Wub Z., Chena M., Preparation and properties of gypsum-based heat storage and preservation material, Energy and Buildings ,2011,43, pg. 2314-2319. https://doi.org/10.1016/j.enbuild.2011.05.016

[14] Z. Lu, B. Xu, J. Zhang, Y. Zhu, G. Sun, Z. Li, Preparation and characterization of expanded perlite/paraffin composite as form-stable phase change material, Solar Energy ,2014, 108, pg. 460-466. https://doi.org/10.1016/i.solener.2014.08.008

[15] Wang C., Feng L., Zeng J., and Tian W., Li X., Shape-stabilized phase change materials based on polyethylene glycol / porous composite: Influence of pore structure of carbon materials, Solar Energy Materials \& Solar Cells, 2012, 105, pg. 21-26. https://doi.org/10.1016/j.solmat.2012.05.031 
[16] Zhang J.W., Guan X.M., Song X.X., Hou H.H.,Yang Z.P., Zhu J.P., Preparation and properties of gypsum based energy storage materials with capric acid palmitic acid/expanded perlite composite PCM, Energy Build, 2015,92 , pg. 155-160. https://doi.org/10.1016/i.enbuild.2015.01.063

[17] Mei B., Zhang, R., Liu Y., Zhang J., Liu, E, Preparation of Capric acid / Halloysite Nanotube Composite as Form-Stable Phase Change Material For Thermal Energy Storage, Solar Energy Materials \& Solar Cells, 2011, 95, pg. 272-277. https://doi.org/10.1016/j.solmat.2011.05.024

[18] Karaipekli A, Sarı A, Capric-myristic acid/expanded perlite composite as form-stable phasechange material for latent heat thermal energy storage, Renewable Energy, 2008, 33 pp. 2599- 2605 https://doi.org/10.1016/j.renene.2008.02.024

[19] Galazutdinova Y, Vega M, Grageda M, Cabeza L.F, Ushak S, Preparation and Characterization of an inorganic magnesium chloride/ nitrate/graphite composite for low temperature energy storage, Solar energy storage and Solar Cells, 2018, 175, pp. 60-70. https://doi.org/10.1016/j.solmat.2017.09.046

[20] Zang C, Zang Z, Ye R, Gao X, Ling Z, Characterization of $\mathrm{MgCl} 2.6 \mathrm{H} 20$-Based Eutectic/Expanded Perlite Composite phase change material with Low Thermal Conductivity, Matrials,2018,11,2369 pp. 1-11. https://doi.org/10.3390/ma11122369

[21] Yılmaz S, Sayın K, Gök Ö, Yılmaz MÖ, Beyhan B, Sahan N, et al. New binary alkane mixtures as pcms for cooling applications. In: 11th International conference on thermal energy storage for energy efficiency and sustainability, June 14-17, 2009, Stockholm International Fairs. Stockholm, Sweden.

[22] Jahanshahi, R. and Akhlaghinia, B. Expanded perlite: an inexpensive natural efficient heterogeneous catalyst for the green and highly accelerated solvent-free synthesis of 5-substituted-1H-tetrazoles using [bmim]N3 and nitriles, Royal Societies of Chemistry, 2015, 5, pg. 104087-104094. https://doi.org/10.1039/C5RA21481E 